\title{
OVERVIEW OF MODERN ANAEROBIC WASTEWATER TREATMENT METHODS
}

\section{PRZEGLAQD NOWOCZESNYCH METOD BEZTLENOWEGO OCZYSZCZANIA ŚCIEKÓW}

DOI: 10.30540/sae-2018-026

\begin{abstract}
A bstract
The paper presents an overview of modern anaerobic wastewater treatment technologies. Characterised reactors for anaerobic wastewater treatment include UASB, ABR, AMBR, ASBR, AnMBR and EGSB reactors. Comparison with aerobic methods shows that use of anaerobic reactors allows for at least three times reduction of the amount sludge. Analysing the disadvantages and advantages of anaerobic wastewater treatment reactors, it can be concluded that their use is beneficial in wastewater treatment plants with problems of high COD concentrations in incoming wastewater and problems of the amount of sewage sludge produced.
\end{abstract}

Keywords: Wastewater treatment, modern wastewater treatment methods, anaerobic reactors, ABR, UASB, AMBR, ASBR, AnMBR, EGSB.

\section{Streszczenie}

$W$ artykule przedstawiono przegląd nowoczesnych metod beztlenowego oczyszczania ścieków. Scharakteryzowano reaktory UASB, ABR, AMBR, ASBR, AnMBR i EGSB. Następnie porównano z metodami tlenowymi, co pokazało, że zastosowanie reaktorów beztlenowych pozwala na co najmniej trzykrotne zmniejszenie ilości osadu. Analizując wady i zalety beztlenowych reaktorów do oczyszczania ścieków, można stwierdzić, że ich zastosowanie jest korzystne w oczyszczalniach ścieków, w których występuja problemy z wysokimi stężeniami ChZT w ściekach naplywających oraz problemy z ilościa wytwarzanego osadu ściekowego.

Słowa kluczowe: oczyszczanie ścieków, nowoczesne metody oczyszczania ścieków, reaktory beztlenowe, ABR, UASB, AMBR, ASBR, AnMBR, EGSB

\section{INTRODUCTION}

Increase in requirements for the quality of treated and discharged sawage from wastewater treatment plants, has made it necessary to search for modern wastewater treatment technologies that increase both technological and economic efficiency.

One of the most significant changes in the process of anaerobic wastewater treatment is the application of the UASB (Upflow Anaerobic Sludge Blanket) already at the end of the 1970s in the Netherlands by Letting and his coworkers [1]. The principal types of anaerobic sludge blanket processes include the original UASB process, as well as modifications to the original solution, the anaerobic baffled reactor (ABR) and anaerobic migrating blanket reactorand (AMBR). The ABR process was developed by McCarty and

\section{WPROWADZENIE}

Wzrost wymagań wobec jakości ścieków oczyszczonych odprowadzanych z oczyszczalni, spowodował konieczność poszukiwania nowoczesnych technologii oczyszczania ścieków, zwiększających ich efektywność pod względem zarówno technologicznym, jak i ekonomicznym.

Jedną z najbardziej znaczących zmian w procesach beztlenowego oczyszczania ścieków jest zastosowanie już pod koniec lat siedemdziesiątych w Holandii przez Lettinga i jego współpracowników reaktora beztlenowego UASB (Upflow Anaerobic Sludge Blanket) [1]. Główne rodzaje beztlenowego procesu powstawania kożucha osadowego zawierają oryginalną wersję procesu UASB oraz modyfikacje pierwotnego rozwiązania pod nazwą: beztlenowy przegrodzony reaktor $\mathrm{ABR}$ 
coworkers at Stanford University in the early 1980s [1]. Treatment of wastewater in anaerobic reactors exploit the process of methanogenesis, that is methane fermentation. Methanogasic processes are used for the treatment of industrial organic waste water, sewage sludge, sewage containing phenol compounds and petroleum-based compounds. Methanogenic bacteria belonging to the Archebacteria group participate in the methane fermentation process. These bacteria are mostly anaerobic thermophilic organisms of varied morphology [2].

In biological-anaerobic reactors, the resulting sediment is in the form of pellets and the microorganisms forming it merge to form specific aggregates as shown in Figure 1.

Wastewater flowing through the reactor is in contact with granules of activated sludge, biodegradable with the release of methane containing gas.

The main advantages of such reactors are that they can be used:

- no necessity to aerate sewage,

- only $2 \%$ to $6 \%$ of the removed COD is converted into excess sludge,

- biogas is obtained from $200 \mathrm{dm}^{3}$ to $1000 \mathrm{dm}^{3}$ per $\mathrm{kg}$ of dry weight of waste,

- half of organic matter is decomposed.

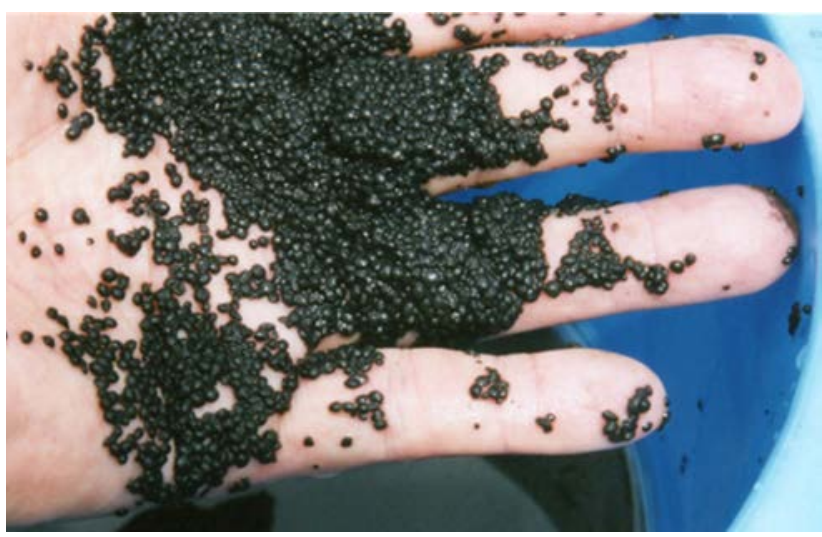

The combination of aerobic and anaerobic systems makes it possible to achieve such good pollutant degradation effects that the treated wastewater is reused in production processes.

\section{UASB REACTORS}

In UASB (Upflow Anaerobic Sludge Bed) reactors, the effluent is fed to the lower reactor section, and then it flows into the upper section of the reactor. The most important elements of the UASB reactors are sewage inlet and outflow systems and special designs for the reception of biogas called bells [4].
(Anaerobic Baffled Reactor) oraz reaktor beztlenowy z migracją kożucha AMBR (Anaerobic Migrating Blanket Reactor). Reaktor ABR został wprowadzony przez McCarty'ego i współpracowników na Uniwersytecie Stanford w połowie lat osiemdziesiątych [1] Oczyszczanie ścieków w beztlenowych reaktorach wykorzystuje proces metanogenezy, czyli fermentacji metanowej. Procesy metanogenezy są wykorzystywane przy oczyszczaniu ścieków organicznych przemysłowych, osadów ściekowych, ścieków zawierających związki fenolu i związki ropopochodne. W procesie fermentacji metanowej udział biorą bakterie metanogenne należące do grupy Archebacteria. Bakterie te są w większości organizmami termofilnymi, beztlenowcami o zróżnicowanej morfologii [2].

W reaktorach biologiczno-beztlenowych powstający osad ma formę granuli, a tworzące go mikroorganizmy, scalając się, tworzą specyficzne agregaty przedstawione na rysunku 1 .

Ścieki przepływając przez reaktor są w kontakcie z granulami osadu czynnego, ulegając biodegradacji $\mathrm{z}$ wydzieleniem gazu zawierającego metan.

Główne zalety wykorzystania takich reaktorów to:

- brak konieczności napowietrzania ścieków,

- jedynie od 2\% do 6\% usuwanego ChZT przekształca się w osad nadmierny,

- uzyskuje się od $200 \mathrm{dm}^{3}$ do $1000 \mathrm{dm}^{3}$ biogazu na 1 kg suchej masy odpadów,

- połowa substancji organicznych ulega rozkładowi.

Fig. 1. Anaerobic activated sludge in the form of pellets [3] Rys. 1. Beztlenowy osad czynny w formie granulat [3]

Połączenie systemów tlenowych i beztlenowych umożliwia uzyskanie tak dobrych efektów degradacji zanieczyszczeń, że oczyszczone ścieki są ponownie wykorzystywane w procesach produkcyjnych.

\section{REAKTORY UASB}

W reaktorach typu UASB (Upflow Anaerobic Sludge Bed) ścieki doprowadzane są do dolnej części reaktora, następnie przepływają w górną jego część. Najważniejszymi elementami reaktorów UASB są instalacje dopływu i odpływu ścieków oraz specjalne konstrukcje do odbioru biogazu, nazywane dzwo- 
Modifications to the UASB reactors can be applied by adding an additional sedimentation tank with reversal of sedimentation or internal closure for increased growth above the activated sludge level. Both modifications are intended to ensure a more effective removal of particulate matter or to change the characterisation and density of the activated sludge [5]. A characteristic process in UASB reactors is the development of dense granulated sludge, which allows the application of high COD loads in comparison to other anaerobic processes.

Due to the formation of flocculant sludge, the solids concentration ranges between 50 and $100 \mathrm{~g} / \mathrm{dm}^{3}$ at the reactor bottom and 5 to $40 \mathrm{~g} / \mathrm{dm}^{3}$ in the more diffuse zone at the top of UASB reactor. Granulated sludge particles have a size range of 1.0 to $3.0 \mathrm{~mm}$ [5]. The development of flocculation depends on the characteristics of the wastewater. Granulation is very effective for wastewater with high content of carbohydrates or sugars, while it is worse for wastewater with high content of protein, which results in more fluffy structure of flocs [6]. Other factors influencing the development of flocculants are $\mathrm{pH}$, flow velocity and nutrients. The $\mathrm{pH}$ should be maintained near 7.0, and a recommended COD:N:P ratio during startup should be 300:5:1 and 600:5:1 during further use [7].

The resulting anaerobic sludge has a specific composition of biocenosis. Acidogenic bacteria formed on the outer part of the flocses, homoocetic bacteria binding hydrogen with carbon dioxide and forming acetates and bacteria reducing sulphates. Methane bacteria Methanosarcin are also found in this layer, using different substrates in the methane fermentation process. Homoocetic bacteria and methane bacteria formed under the outer layer, using hydrogen and carbon dioxide in biochemical processes. Methane bacteria multiply in the central part of the sludge, using acetates as a substrate for biochemical changes. These are mainly Methanosaeta bacteria [8].

Such a structure of flocculants makes it possible that organic odorous gases are not emitted from the UASB reactors, but the presence of hydrogen sulphide is always found in biogas. Therefore, structural elements above the sewage surface must be made of materials resistant to biochemical corrosion by aerobic sulphuric bacteria [9].

Table 1 provides guidance for the design of anaerobic UASB reactors operating under psychrophilic conditions. nami [4]. Można zastosować modyfikacje reaktorów UASB poprzez włączenie dodatkowego zbiornika sedymentacji z zawracaniem osadu lub zamknięcie wewnętrzne dla zwiększonego wzrostu powyżej poziomu osadu czynnego. Obie modyfikacje mają na celu zapewnienie skuteczniejszego usuwania cząstek stałych lub zmianę charakterystyki osadu czynnego i jego gęstości [5]. Charakterystycznym procesem w reaktorach UASB jest rozwój gęstego osadu granulowanego, co pozwala na zastosowanie wysokich obciążeń ładunkiem ChZT w stosunku do innych procesów beztlenowych.

Poprzez powstawanie kłaczkowatego osadu stężenie cząstek stałych waha się między 50 a $100 \mathrm{~g} / \mathrm{dm}^{3} \mathrm{w}$ dnie reaktora oraz między 5 a $40 \mathrm{~g} / \mathrm{dm}^{3}$ w strefach większego rozproszenia górnej części reaktora. Granulowane cząstki osadu wahają się w swoich rozmiarach od 1,0 do 3,0 mm [5]. Rozwój kłaczków zależy od charakterystyki ścieków. Granulacja jest bardzo skuteczna dla ścieków z dużą zawartością węglowodanów lub cukrów, natomiast gorzej wypada przy ściekach z wysoką zawartością białka, co prowadzi do powstawania bardziej puszystej budowy kłaczków [6]. Innymi czynnikami wpływającymi na rozwój kłaczków są: pH, prędkość przepływu oraz dodatek składników odżywczych. Rekomendowany odczyn powinien być utrzymany w okolicach $\mathrm{pH}$ równego 7 . Stosunek ChZT:N:P w fazie uruchomienia powinien wynosić 300:5:1, natomiast podczas dalszego użytkowania 600:5:1 [7].

Powstający osad beztlenowy ma specyficzny skład biocenozy. Na zewnętrznej części kłaczków rozwijają się bakterie kwasogenne, bakterie homooctanowe wiążące wodór $\mathrm{z}$ dwutlenkiem węgla i tworzące octany oraz bakterie redukujące siarczany. W warstwie tej znajdują się także bakterie metanowe Methanosarcina, wykorzystujące różne substraty w procesie fermentacji metanowej. Pod zewnętrzną warstwą rozwijają się bakterie homooctanowe oraz bakterie metanowe wykorzystujące $\mathrm{w}$ procesach biochemicznych wodór i dwutlenek węgla. W centralnej części osadu namnażają się bakterie metanowe, wykorzystujące octany jako substrat przemian biochemicznych. Są to głównie bakterie Methanosaeta [8].

Taka budowa struktury kłaczków powoduje, że nie wydzielają się z reaktorów UASB organiczne gazy odorowe, ale w biogazie zawsze stwierdza się obecność siarkowodoru. Z tego względu elementy konstrukcyjne, znajdujące się powyżej powierzchni ścieków, muszą być wykonane z materiałów odpornych na korozję biochemiczną wywołaną przez tlenowe bakterie siarkowe [9]. 
Table 1 Table of UASB wastewater treatment plants operation parameters, own elaboration based on [5] Tabela 1. Tabela dotycząca parametrów użytkowania reaktorów UASB na oczyszczalni, opracowanie własne na podstawie [5]

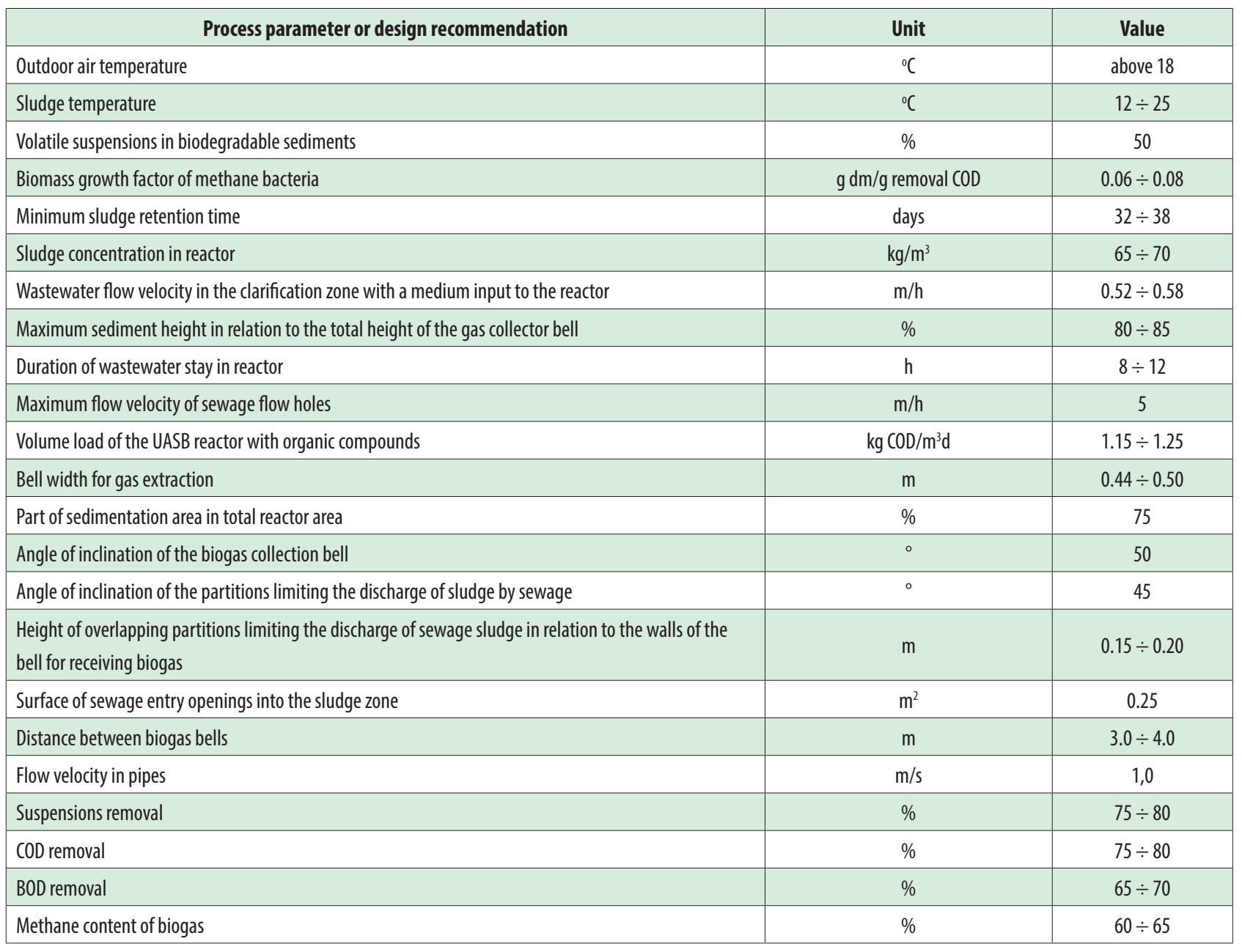

\section{ABR REACTORS}

The construction scheme of the ABR reactor is shown in Figure 2. The reactor is equipped with partitions to force the direction of sewage flow through a series of chambers. The inlet sewage to the reactor septum is directed vertically downwards, and then on the outlet upwards. The sludge in the reactor floats and sinks, flowing between the chambers producing biogas [10]. The sewage flow is carried out at low speed, which causes the time of sewage contact with the granules of the activated sludge, leading to improved treatment processes. Different types of modifications to the ABR reactor improve efficiency on a case-by-case basis. ABR reactors are characterized by simple construction, easy to operate and high resistance to hydraulic loads. The sectional construction allows for separation of wastewater retention time with hydraulic retention time, which results in anaerobic wastewater treatment in short
W tabeli 1 przedstawiono wytyczne do projektowania beztlenowych reaktorów UASB pracujących w warunkach psychrofilnych.

\section{REAKTORY ABR}

Schemat budowy reaktora ABR został przedstawiony na rysunku 2. Reaktor został wyposażony w przegrody w celu wymuszenia kierunku przepływu ścieków przez serię komór. Ścieki na dopływie do przegrody reaktora kierowane są pionowo w dół, a następnie na odpływie do góry.

Osad w reaktorze unosi się i opada, przepływając między komorami, produkując biogaz [10]. Przepływ ścieków odbywa się z małą prędkością co powoduje wydłużenie czasu kontaktu ścieków z granulami osadu czynnego, prowadząc do poprawy procesów oczyszczania. Różne rodzaje modyfikacji reaktora ABR poprawiają wydajność w zależności od konkretnego przypadku. Reaktory 
time units, usually several hours [11]. ABR reactors are suitable for a wide range of urban wastewater as well as industrial wastewater, but their efficiency decreases with an increase in organic content.

Table 2 shows the reductions in COD of effluent entering the reactor according to its origin. Therefore, ABR reactors are particularly suitable for wastewater with a high percentage of solids that do not drop down and a narrow BOD-COD ratio. These reactors are usually used in local wastewater treatment plants, in combination with other treatment processes [12].
ABR charakteryzują się prostą budową, łatwością w obsłudze, a także dużą odpornością na obciążenia hydrauliczne. Przegrodowa konstrukcja pozwala na zróżnicowanie czasu zatrzymania ścieków z czasem retencji hydraulicznej, dzięki czemu oczyszczanie ścieków w warunkach beztlenowych odbywa się w czasie zaledwie kilku godzin [11]. Reaktory ABR są odpowiednie dla szerokiego zakresu ścieków komunalnych, jak również ścieków przemysłowych, jednakże ich efektywność spada wraz ze wzrostem zawartości substancji organicznych. W tabeli 2 przedstawiono redukcje ChZT ścieków dopływających do reaktora $\mathrm{w}$ zależności od ich pochodzenia. W związku z tym reaktory ABR są szczególnie odpowiednie dla ścieków z wysokim procentem zawartości nieopa-

Table 2. Table showing the type of effluent entering the ABR reactor and the COD reductions. Own adaptation based on [1] Tabela 2. Tabela przedstawiająca rodzaj ścieków doptywajacych do reaktora ABR oraz redukcje ChZT. Własna adaptacja na podstawie [1]

\begin{tabular}{|c|c|c|c|c|c|}
\hline Wastewater & Temperature $\left[{ }^{\circ} \mathrm{C}\right]$ & Number of chambers & Influent COD $\left[\mathrm{gCOD} / \mathrm{m}^{3}\right]$ & COD loading [kg COD/ d] & $\%$ COD removal \\
\hline Malasses & 35 & 3 & $115 \div 900$ & $4.3 \div 28$ & $49 \div 88$ \\
\hline Swine manure & 35 & 3 & 58.5 & 4 & $62 \div 69$ \\
\hline Municipal wastewater & $18 \div 28$ & 3 & $0.26 \div 0.55$ & 2.2 & 90 \\
\hline Slaughterhouse & $25 \div 30$ & 4 & $0.45 \div 0.55$ & $0.9-4.7$ & $75 \div 90$ \\
\hline Pharmaceutical & 35 & 5 & 20 & 20 & $36 \div 68$ \\
\hline Industrial & 15 & 8 & 0.31 & 0.9 & 70 \\
\hline
\end{tabular}

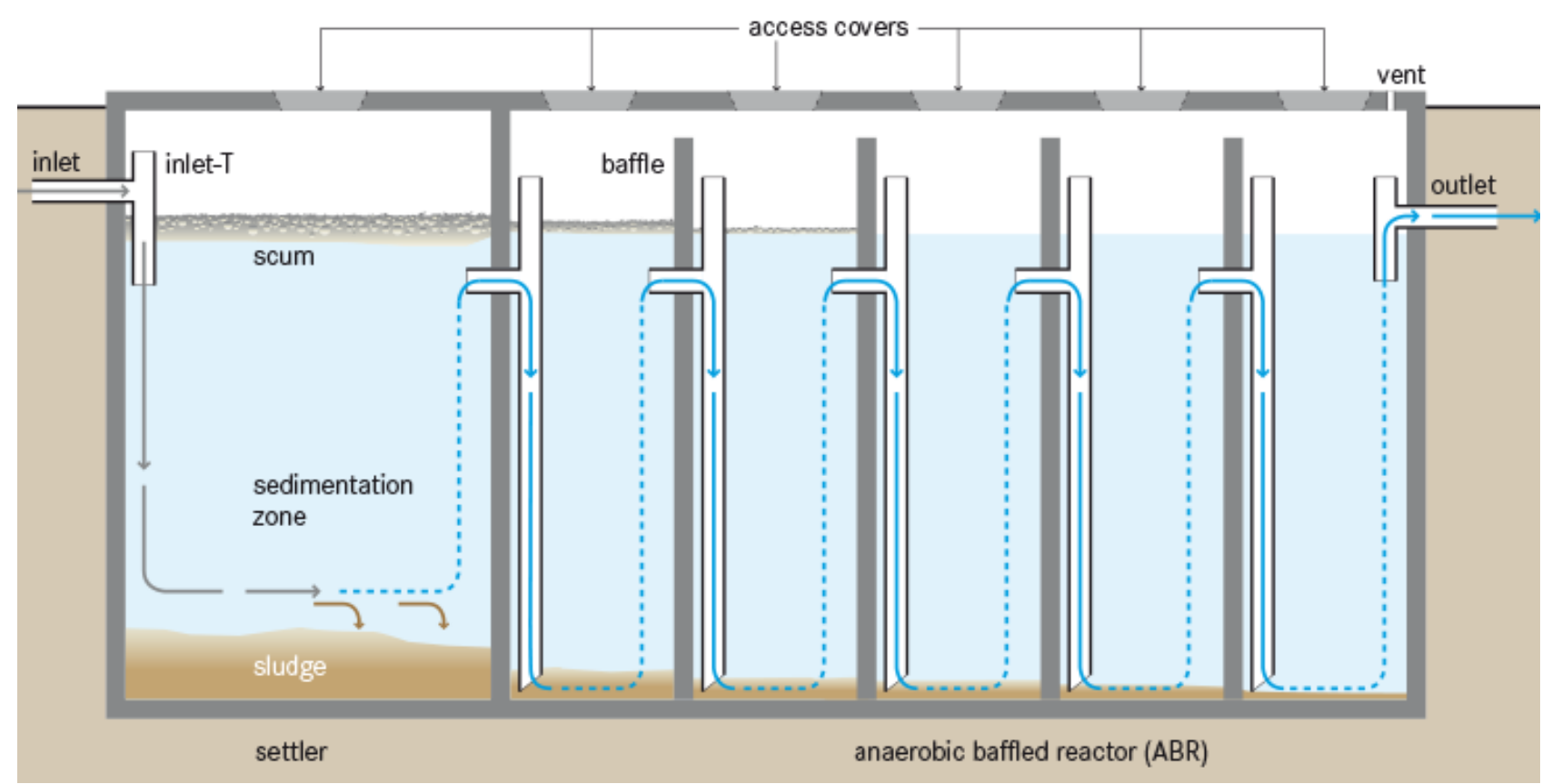

Fig. 2. Schematic of ABR reactor operation [13]

Rys. 2. Schemat działania reaktora $A B R$ [13] 


\section{AMBR REACTORS}

The principle of AMBR (Anaerobic Migrating Blanket Reactor) operation is similar to that of ABR reactors with adding mechanical mixing in each chamber to maintain the sludge in continuous operation. The feeder sewage flow point is periodically changed with the outlet point, which is the original inlet point. In this way, the active sludge blanket in an anaerobic reactor remains more homogeneous. The direction of sewage flow is reversed when a significant amount of solids has settled in the last chamber [14]. The principle of operation of the AMBR is shown in Figure 3.

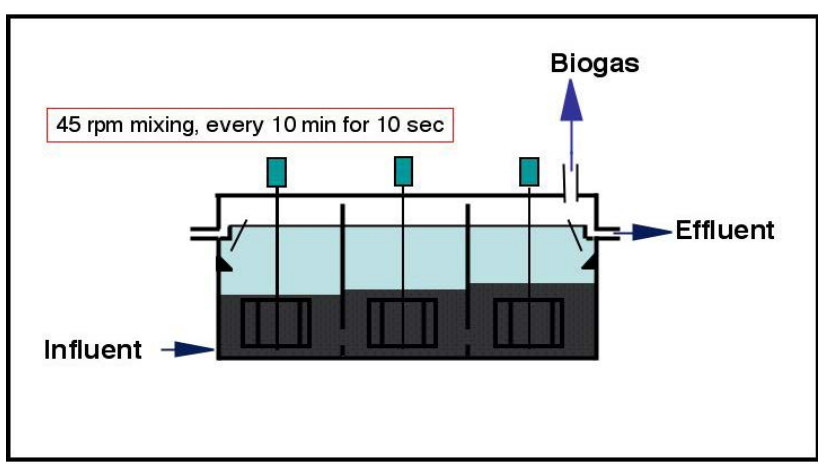

\section{ASBR REACTORS}

The ASBR is a modern high performance anaerobic reactor. Its development is attributed to research in the early 1960s by the Dague (1967). In his research Dague studied the influence of biofloculation on sludge and its deposition under anaerobic conditions. The reactors used in the study were operated in batch mode with separation of solids. Studies have shown that the batch process was capable of separating the sludge retention time from hydraulic retention time. The process is called, ,anaerobic active sludge" [3]. Recent research at the Iowa State University has expanded Dague's previous studies on the development of a modern, high performance anaerobic anaerobic process, which has been named ASBR (Anaerobic Sequencing Batch Reactor) [ASBR - US patent No. 5,185,079]. The ASBR process consists of four sequential steps: growth, reaction, settle phase, decant phase, as shown in Figure 4; during the growth phase, the substrate is added to a reactor where continuous mixing takes place in the reactor. The substrate concentration and metabolic factors increase to their maximum value during the dających zawiesin stałych oraz wąskim stosunkiem BZT do ChZT. Reaktory te są zwykle stosowane w lokalnych oczyszczalniach ścieków w połączeniu $\mathrm{z}$ innymi procesami oczyszczania [12].

\section{REAKTORY AMBR}

Zasada działania reaktora AMBR (Anaerobic Migrating Blanket Reactor) jest podobna jak przy reaktorach ABR z dodatkiem mechanicznego mieszania w każdej komorze w celu utrzymania osadu w ciągłym ruchu. Punkt dopływu ścieków zasilających jest okresowo zmieniany z punktem odpływu, ten natomiast zajmuje pierwotne miejsce dopływu. W ten sposób warstwa kożucha osadu czynnego w reaktorze beztlenowym pozostaje bardziej jednorodna. Kierunek przepływu ścieków zostaje odwrócony gdy znaczna ilość ciał stałych osadziła się w ostatniej komorze [14]. Zasadę działania reaktora AMBR przedstawiono na rysunku 3.

Fig. 3. Schematic of the three-chamber AMBR reactor [15] Rys. 3. Schemat trzykomorowego reaktora AMBR [15]

\section{REAKTORY ASBR}

Reaktor ASBR jest nowoczesnym wysoko wydajnym reaktorem beztlenowym. Jego rozwój przypisywany jest do badań na początku lat sześćdziesiątych przez Dague (1967). W swoich badaniach Dague zajmował się wpływem bioflokulacji na osad i jego osadzanie w warunkach beztlenowych. Reaktory użyte w badaniach były eksploatowane w trybie wsadowym z separacją ciał stałych. Badania wykazały, że proces wsadowy był zdolny do oddzielenia czasu retencji osadu od czasu zatrzymania. Proces nazwano „,beztlenowym osadem czynnym" [3]. Niedawne badania na Iowa State University rozszerzyły wcześniejsze studia Dague na temat opracowania nowoczesnego, wysoko wydajnego procesu beztlenowego, który nazwano reaktorem ASBR (Anaerobic Sequencing Batch Reactor) [Reaktor ASBR - patent USA nr 5,185,079]. Proces działania reaktora ASBR obejmuje cztery sekwencyjne etapy: wzrostu, reakcji, osadzania i dekantacji, co przedstawia rysunek 4. Podczas etapu wzrostu następuje dodanie substratu do reaktora, podczas którego w reaktorze odbywa się stałe mieszanie. Stężenie substratów i wskaźniki metaboliczne wzrastają 
growth phase. The volume of the substrate depends on many factors, including the desired retention time [7], organic load and expected sediment values. The reaction stage is crucial for the conversion of organic substances into biogas. The time needed to react depends on the required leakage quality and biomass concentration, temperature, substrate properties and loading rate of organic substances. The settle phase requires only mixing, allowing the biomass to settle inside the reactor. The required time for the settle stage depends on biomass concentration, temperature and the type of biomass (floculant or granulate) [16]. Once settle is complete, decanting takes place. The ASBR reactor system has unique characteristics that make it possible to achieve a high level of organic particles removal. One of them is the change in the substrate concentration in the reactor from high concentrations during and immediately after low concentrations at the end of the reaction cycle, just before biomass deposition and wastewater discharge. This causes the nutrient and microbial ratio to be high immediately after growth and low just before deposition, as shown in Figure 5 [17]. do ich maksymalnej wartości w trakcie etapu wzrostu. Objętość substratu zależy od wielu czynników, w tym pożądanego czasu zatrzymania [7], obciążenia organicznego oraz oczekiwanych wartości osadowych. Etap reakcji jest kluczowy w przemianie substancji organicznych do biogazu. Czas potrzebny na reakcje jest zależny od wymaganej jakości wycieku oraz od stężenia biomasy, temperatury, właściwości podłoża oraz współczynnika załadunku substancji organicznych. Etap osadzania wymaga wyłącznie mieszania, umożliwiając osadzenie się biomasy wewnątrz reaktora. Wymagany czas dla etapu osadzania zależy od stężenia biomasy, temperatury oraz od rodzaju biomasy (flokulant lub granulat) [16]. Po zakończeniu osadzania następuje proces dekantacji. System reaktorów ASBR posiada unikalne cechy charakterystyczne, umożliwiające osiągnięcie wysokiego poziomu usuwania substancji organicznych. Jedną z nich jest zmiana stężenia substratu $\mathrm{w}$ reaktorze $\mathrm{z}$ wysokich stężeń podczas i bezpośrednio po podaniu do niskich stężeń w zakończeniu cyklu reakcji, tuż przed osadzaniem biomasy i odprowadzaniem ścieków. To powoduje, że stosunek pożywki do mikroorganizmów jest wysoki zaraz po wzroście, a niski tuż przed osadzaniem, co przedstawia rysunek 5 [17].

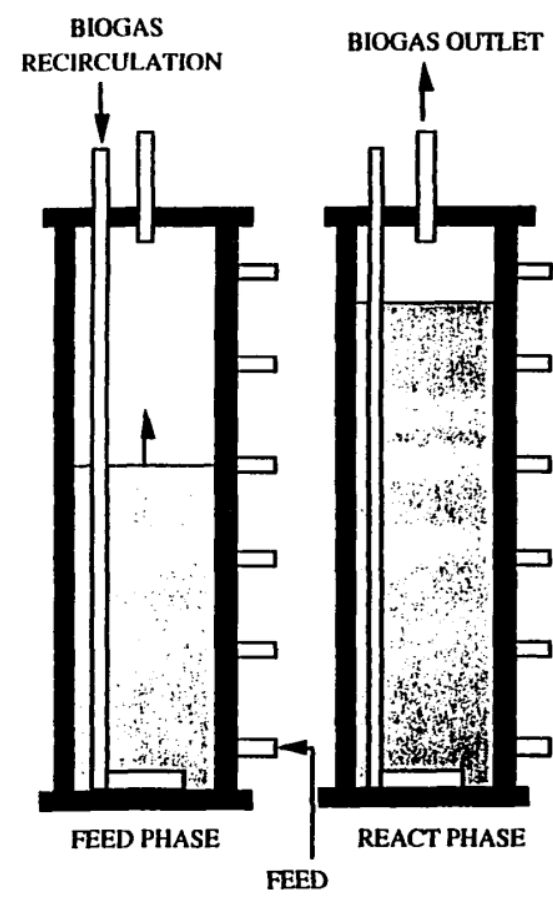

Fig. 4. Shcematic of ASBR reactor operation [17] Rys. 4. Schemat działania reaktorów ASBR [17]
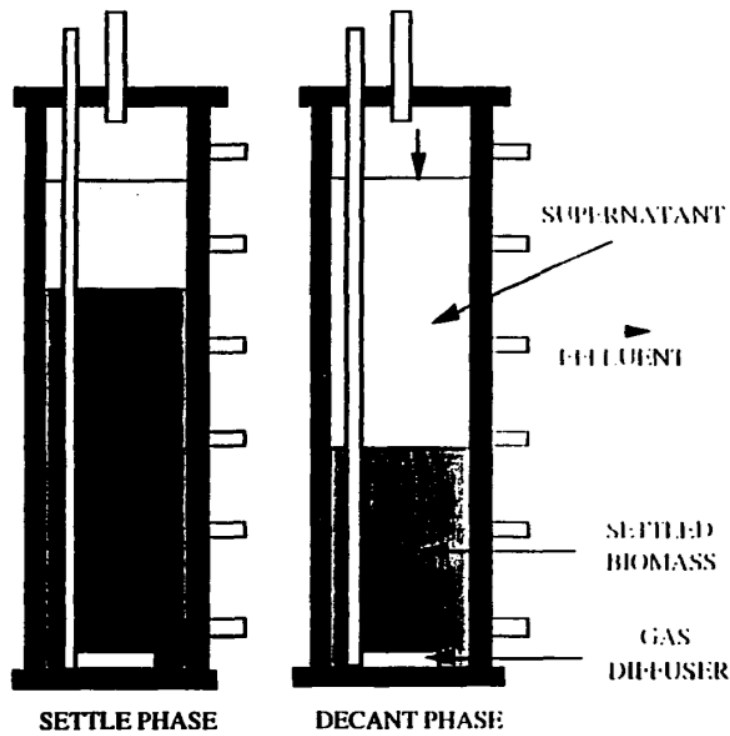


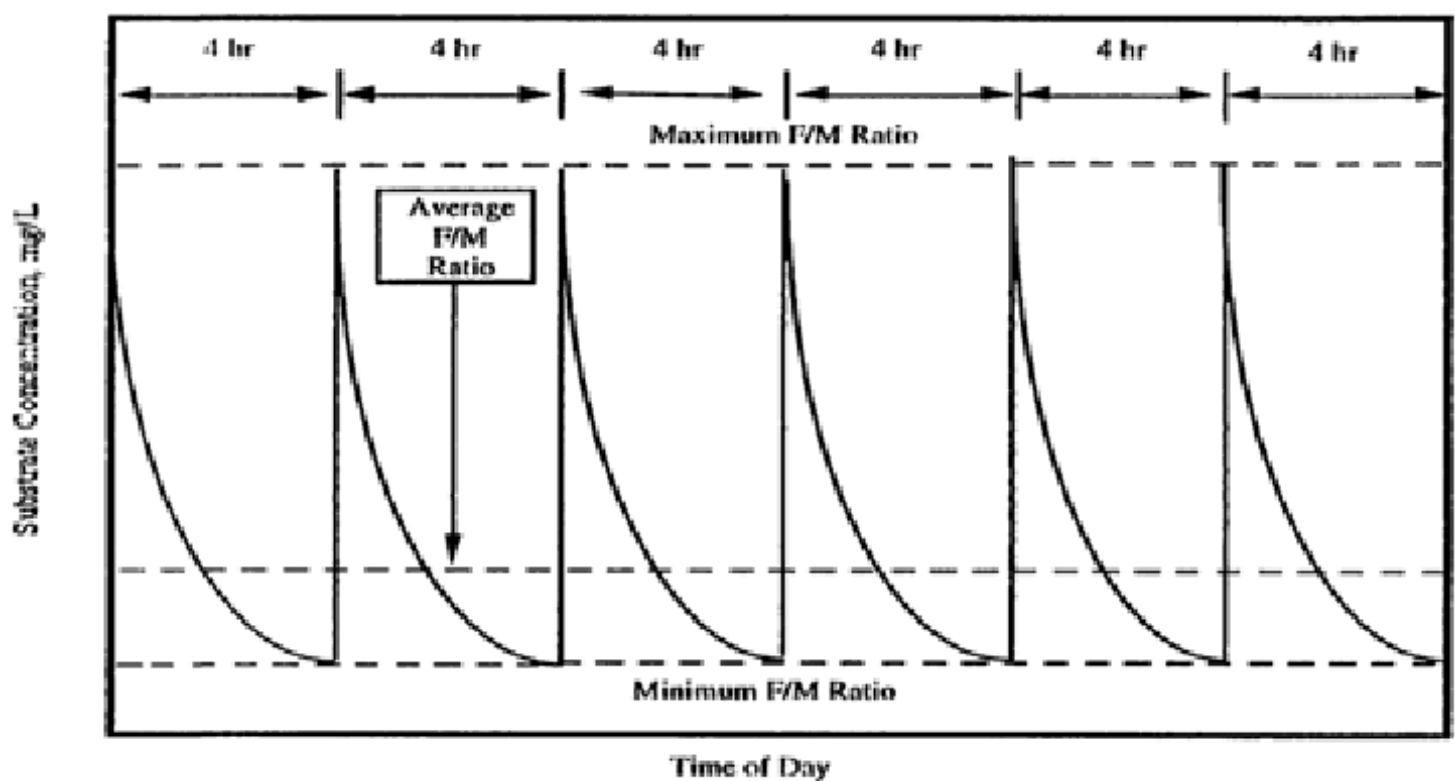

Fig. 5. The ratio of culture medium to micro-organisms after growth phase and before deposition [17]

Rys. 5. Stosunek pożywki do mikroorganizmów po fazie wzrostu i przed faza osadzania [17]

\section{AnMBR REACTORS}

One of the most advanced solutions to improve the efficiency of anaerobic wastewater treatment is the use of an anaerobic reactor integrated with the filtration membrane. In this system, during the membrane filtration process, treated sewage can be separated from anaerobic biomass and at the same time biomass can be concentrated in the bioreactor to the desired level [17]. The AnMBR concept was developed in the 1980s, but the use of this technology was limited by concerns about membrane pollution and energy consumption in membrane processes. However, with the success of MBR technology in recent years, membrane filtration has become increasingly common in biological wastewater treatment [18]. These advances have stimulated increased research interest in AnMBR technology. Anaerobic membrane bioreactor is an integrated system of anaerobic bioreactor and low-pressure ultrafiltration or membrane microfiltration. These membranes may retain solid suspensions, including biomass and inert solids [18]. AnMBR technology can achieve complete separation of the sawage retention time from the hydraulic retention time, regardless of sewage quality, biological processes and sediment conditions and properties. As shown in Figure 6, the filtration membrane can be integrated with a bioreactor in three different forms: internal immersion (a), external submersion (b) and crossflow (c). AnMBR systems have been tested to treat

\section{REAKTORY AnMBR}

Jedną z bardziej zaawansowanych rozwiązań poprawiających skuteczność beztlenowego oczyszczania ścieków jest użycie beztlenowego reaktora zintegrowanego $\mathrm{z}$ membraną filtracyjną. W tym systemie podczas procesu filtracji membranowej można oddzielić oczyszczone ścieki od beztlenowej biomasy, a jednocześnie koncentrować biomasę w bioreaktorze do pożądanego poziomu [17]. Koncepcja AnMBR została opracowana w latach osiemdziesiątych, jednakże stosowanie tej technologii zostało ograniczone przez obawy dotyczące zanieczyszczenia środowiska przez membrany oraz zużycia energii przy procesach membranowych. Jednak wraz z sukcesem technologii MBR, w ostatnich latach zaczęto coraz częściej stosować filtrację membranową przy biologicznym oczyszczaniu ścieków [18]. Te postępy stymulowały zwiększone zainteresowanie badawcze dotyczące technologii AnMBR. Bioreaktor beztlenowy membranowy jest zintegrowanym systemem bioreaktora beztlenowego i ultrafiltracji pod niskim ciśnieniem lub mikrofiltracji membranowej. Membrany te mogą zatrzymywać zawiesiny stałe, w tym biomasę i obojętne ciała stałe [18]. Technologia AnMBR może osiągnąć całkowite oddzielenie czasu retencji cząstek stałych od czasu retencji hydraulicznej, niezależnie od jakości ścieków, procesów biologicznych oraz warunków i właściwości osadów. Jak przedstawiono na rysunku 6 , membrana filtracyjna może być zintegrowana $\mathrm{z}$ bioreaktorem 
a wide range of wastewater. It has been shown with AnMBR that can reach $90 \%$ or more of the COD reductions. The load load of COD varies from 5 to $30 \mathrm{~kg} / \mathrm{m}^{3} \mathrm{~d}$, hydraulic retention time from 1 to 25 days, methane production from 0.25 to $0.35 \mathrm{~m}^{3}$ $\mathrm{CH}_{4} / \mathrm{kg} \mathrm{COD}$, suspended solids from 15 to $30 \mathrm{~g} / \mathrm{m}^{3}$. Laboratory cost analysis showed that the cost of using AnMBR can be as much as 1/3 of the costs using oxygen processes [19]. Methane production energy can balance the energy required to treat membrane biogas. The temperature range for effective anaerobic wastewater treatment ranges from $20^{\circ} \mathrm{C}$ to $30^{\circ} \mathrm{C}$, which may make it difficult to treat wastewater during the frostier winter, as it is not possible to heat a large amount of wastewater for economic reasons [20].

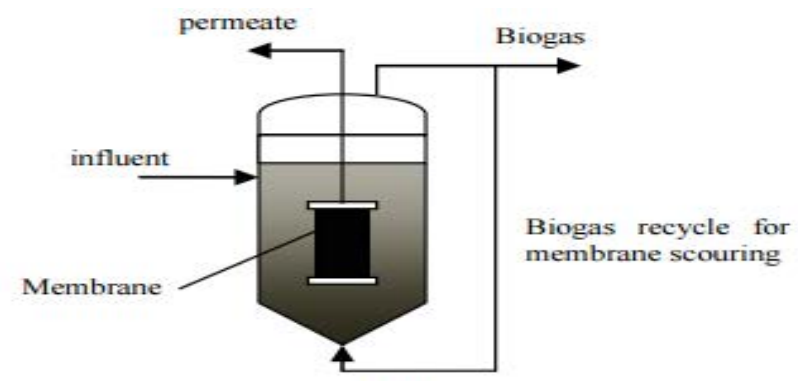

(a)

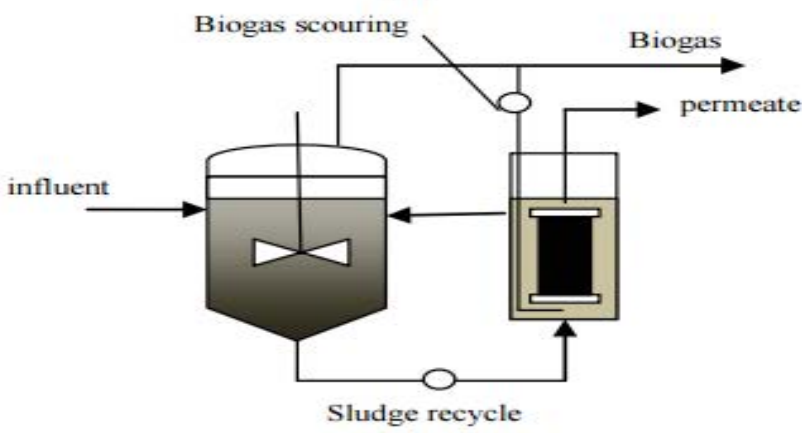

(b)

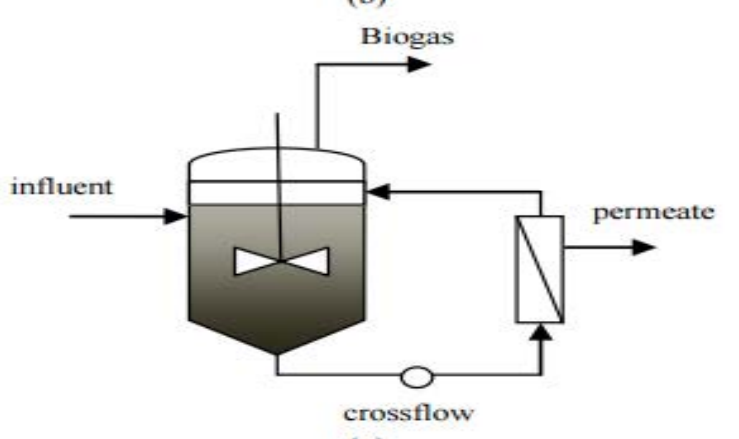

(c) w trzechróżnych formach:wewnętrznejzanurzeniowej (a), zewnętrznej zanurzeniowej (b) oraz zewnętrznej z przepływem krzyżowym (c). Systemy AnMBR zostały testowane w celu oczyszczania szerokiego zakresu ścieków. Wykazano że AnMBR mogą osiągnąć wartości 90\% lub więcej redukcji ChZT. Obciążenie ładunkiem ChZT waha się od 5 do $30 \mathrm{~kg} / \mathrm{m}^{3} \mathrm{~d}$, czas retencji hydraulicznej od 1 do $25 \mathrm{dni}$, wytwarzanie metanu od 0,25 do $0,35 \mathrm{~m}^{3} \mathrm{CH}_{4} / \mathrm{kg}$ ChZT, cząstki stałe zawieszone od 15 do $30 \mathrm{~g} / \mathrm{m}^{3}$. Analiza kosztów przeprowadzona laboratoryjnie wykazała, że koszt użytkowania AnMBR może wynosić nawet $1 / 3$ kosztów przy użyciu procesów tlenowych [19]. Energia wytwarzana przy produkcji metanu może zrównoważyć energię wymaganą do oczyszczenia biogazu membranowego. Zakres temperatur dla skutecznego oczyszczania beztlenowego ścieków wynosi od $20^{\circ} \mathrm{C}$ do $30^{\circ} \mathrm{C}$, przez co kłopotliwe może się okazać oczyszczanie ścieków w czasie mroźniej zimy, ponieważ ze względów ekonomicznych nie jest możliwe podgrzanie dużej ilości ścieków [20].

Fig. 6. Different configurations of AnMBR reactors: a) AnMBR submerged membrane system; b) AnMBR submerged separately; c) AnMBR submerged separately and cross-flow [21]

Rys. 6. Różne konfiguracje reaktorów AnMBR: a) system zanurzonej membrany AnMBR; b) AnMBR z zanurzona oddzielnie membrana; c) AnMBR z zanurzona oddzielnie membrana i przeptywem krzyżowym [21] 


\section{EGSB REACTORS}

The EGSB reactor is a modified version of the UASB reactor. The reactor is a vertical tank 13 to 16 $\mathrm{m}$ high [22]. It is characterized by a sewage flow rate of more than $6 \mathrm{~m} / \mathrm{h}$, while in UASB reactors it is from 0.5 to $1.0 \mathrm{~m} / \mathrm{h}$ [23]. The reactor provides maximum stability thanks to an automatically adjustable external recirculation system. Due to such a high flow rate (which means that the mixing capacity is increased), granules are more likely to come into contact with wastewater. Another advantage of the higher velocity is the ability to separate the dispersed sludge from the mature granules in the reactor. The outflow concentration of COD is generally lower than $1 \div 2 \mathrm{~g} / \mathrm{m}^{3}$ [24]. Biogas is discharged under low overpressure. Additional biogas facilities such as dehumidifiers, compressors or biogas tanks are therefore not necessary [22].

\section{COMPARISON OFAEROBICAND ANAEROBIC METHODS}

Table 3 shows the basic parameters of anaerobic sludge with the removal of organic compounds (carbon compounds), in the methane fermentation process and active sludge working under aerobic conditions (aerobic-anoxic-anaerobic) suitable for the removal of carbon, nitrogen and phosphorus compounds. When treating sewage under anaerobic

\section{REAKTORY EGSB}

Reaktor EGSB jest zmodyfikowaną wersją reaktora UASB. Reaktor jest pionowym zbiornikiem o wysokości od 13 do $16 \mathrm{~m}$ [22]. Charakteryzuje się prędkością przepływu ścieków utrzymującą się powyżej $6 \mathrm{~m} / \mathrm{h}$, podczas gdy w reaktorach UASB wynosi ona od 0,5 do $1,0 \mathrm{~m} / \mathrm{h}$ [23]. Reaktor zapewnia maksymalną stabilność pracy dzięki automatycznie regulowanemu systemowi recyrkulacji zewnętrznej. Ze względu na tak dużą prędkość przepływu (co oznacza zwiększenie wydajności mieszania) granulaty mają większą możliwość kontaktu ze ściekami. Dzięki temu reaktor oczyszcza ścieki przy wysokim obciążeniu ładunkiem związków organicznych nawet do $30 \mathrm{~kg} \mathrm{ChZT} / \mathrm{d} \mathrm{m}^{3}$. Kolejną zaletą wyższej prędkości jest możliwość oddzielenia rozproszonego osadu od dojrzałych granul w reaktorze. Stężenie ChZT na wypływie jest przeważnie niższe niż $1 \div 2 \mathrm{~g} / \mathrm{m}^{3}$ [24]. Biogaz odprowadzany jest pod małym nadciśnieniem. Dodatkowe urządzenia biogazowe, takie jak: osuszacze, sprężarki lub zbiorniki biogazowe, nie są zatem konieczne [22].

\section{PORÓWNANIE METOD TLENOWYCH I BEZTLENOWYCH}

$\mathrm{W}$ tabeli 3 przedstawiono podstawowe parametry osadu czynnego beztlenowego z usuwaniem związków organicznych (związków węgla) w procesie fermentacji metanowej oraz osadu czynnego pracującego w warunkach tlenowych (tlenowo-anoksyczno-beztlenowych), przystosowanego do usuwania związków węgla, azotu i fosforu. Podstawową korzyścią wynika-

Table 3. Comparison of basic technological parameters of anaerobic and aerobic sludge[8]

Tabela 3. Porównanie podstawowych parametrów technologicznych osadu czynnego beztlenowego i tlenowego [8]

\begin{tabular}{|c|c|c|}
\hline Characteristic feature of the process & $\begin{array}{c}\text { Wastewater treatment in anaerobic } \\
\text { conditions. Anaerobic sludge }\end{array}$ & $\begin{array}{c}\text { Conducting wastewater treatment in aerobic conditions } \\
\text { Aerobic activated sludge }\end{array}$ \\
\hline Loading chamber volume applied & & $0.5 \div 1.5 \mathrm{~kg} \mathrm{COD} / \mathrm{m}^{3} \mathrm{~d}$ \\
\hline Psychophilic conditions temperature $10 \div 20^{\circ} \mathrm{C}$ & to $4.0 \mathrm{~kg} \mathrm{COD} / \mathrm{m}^{3} \mathrm{~d}$ & \\
\hline Mesophilic conditions temperature $30 \div 37^{\circ} \mathrm{C}$ & to $20.0 \mathrm{~kg} \mathrm{COD} / \mathrm{m}^{3} \mathrm{~d}$ & $0.35 \div 0.45 \mathrm{~g} \mathrm{dm} / \mathrm{g} \mathrm{COD}$ \\
\hline Thermophilic conditions temperature $40 \div 50^{\circ} \mathrm{C}$ & to $40 \mathrm{~kg} \mathrm{COD} / \mathrm{m}^{3} \mathrm{~d}$ & $0.15 \div 0.75 \mathrm{~g} \mathrm{COD} / \mathrm{g} \mathrm{dm}$ \\
\hline Biomass increase index & $0.05 \div 0.15 \mathrm{~g} \mathrm{dm} / \mathrm{g} \mathrm{COD}$ & $16 \div 24 \mathrm{hours}$ \\
\hline Charged load of COD of sludge dry mass & $0.75 \div 1.50 \mathrm{~g} \mathrm{COD} / \mathrm{g} \mathrm{dm}$ & $1 \div 3$ weeks \\
\hline Time of wastewater retention in the activated sludge cham- & $20 \div 24 \mathrm{hours}$ & \\
\hline bers & $3 \div 4 \mathrm{months}$ & \\
\hline Time of working of the activated sludge chambers & $1 \div 2 \mathrm{months}$ & \\
\hline Psychophilic conditions $10 \div 20^{\circ} \mathrm{C}$ & $2 \div 3$ months & \\
\hline Mesophilic conditions $30 \div 37^{\circ} \mathrm{C}$ & & \\
\hline Thermophilic conditions $40 \div 50^{\circ} \mathrm{C}$ & & \\
\hline
\end{tabular}


conditions, the main benefit results from lower, on average around 4 times, growths of excess sludge compared to aerobic conditions, which significantly reduces the costs of sewage sludge disposal.

\section{CONCLUSION}

The use of anaerobic reactors allows for at least three times reduction of the amount sludge (0.05 $\div 0.15 \mathrm{~g} \mathrm{dm} . / \mathrm{g} \mathrm{COD})$ in comparison to oxygen conditions $(0.35 \div 0.45 \mathrm{~g} \mathrm{dm}$./g COD). The anaerobic activated sludge is characterised by the permissible load capacity of COD up to $30 \mathrm{~kg} / \mathrm{d}-\mathrm{m}^{3}$ (EGSB highperformance reactors). Anaerobic activated sludge is an advantageous solution in case of high COD load loads. The big advantage of using anaerobic systems is the reduction of plant operating costs by using biogas.

Anaerobic reactor defects are highly sensitive to environmental changes (temperature, $\mathrm{pH}$ ). It is not possible to effectively remove nutrients. It is also necessary to treat wastewater by aerobic methods and use equalization tanks.

Analysing the disadvantages and advantages of anaerobic wastewater treatment reactors, it can be concluded that their use is beneficial in wastewater treatment plants with problems of high COD concentrations in incoming wastewater and problems of the amount of sewage sludge produced. jącą z oczyszczania ścieków w warunkach beztlenowych jest zmniejszenie prawie czterokrotnie przyrostu osadu nadmiernego,w porównaniu do warunków tlenowych, a to przekłada się na znaczne obniżenie kosztów utylizacji osadów ściekowych.

\section{WNIOSKI}

Zastosowanie beztlenowych reaktorów pozwala na co najmniej trzykrotne zmniejszenie ilości powstających osadów $(0,05 \div 0,15$ g s.m./g ChZT $)$ w porównaniu do warunków tlenowych $(0,35 \div 0,45 \mathrm{~g}$ s.m./g ChZT). Beztlenowy osad czynny charakteryzuje się dopuszczalną wielkością obciążenia ładunkiem ChZT nawet do $30 \mathrm{~kg} / \mathrm{d} \cdot \mathrm{m}^{3}$ (wysokosprawne reaktory EGSB). Beztlenowy osad czynny sprawdza się jako korzystne rozwiązanie w przypadku wysokich obciążeń ładunkiem ChZT. Dużą zaletą wykorzystywania systemów beztlenowych jest obniżenie kosztów eksploatacyjnych oczyszczalni poprzez wykorzystanie powstającego biogazu.

Wadą beztlenowych reaktorów jest znaczna wrażliwość bakterii metanogennych na zmiany środowiskowe (temperatura, pH). Nie ma możliwości efektywnego usunięcia związków biogennych. Konieczne jest także doczyszczenie ścieków metodami tlenowymi oraz zastosowanie zbiorników wyrównawczych.

Analizując wady i zalety beztlenowych reaktorów służących do oczyszczania ścieków, można stwierdzić, że korzystne jest ich zastosowanie w oczyszczalniach borykających się z problemami wysokich stężeń ładunków ChZT w ściekach dopływających oraz z problemami ilości powstających osadów ściekowych.

\section{References}

[1] Metcalf \& Eddy Inc,; George Tchobanoglous,; Franklin L Burton,; H.David Stensel. Wastewater Engineering: Treatment and Reuse 4th Edition. Chicago 2003.

[2] Gumińska J., Barbusiński K.: Kierunki rozwoju innowacyjnych technologii oczyszczania wody iścieków w perspektywie 2015-2020. Aktualne Zagadnienia w Inżynierii Środowiska (Barbusiński K. red.). Monografia. Politechnika Śląska, Gliwice 2015, p. 119-130.

[3] http://www.apec-vc.or.jp/e/modules/tinyd00/?id=81\&kh_open_cid_00=2 access 23.10.2017

[4] Wojtachnio K.: Nowoczesne technologie w inżynierii środowiska. ,,Biuletyn Politechniki Ślaskiej” 12/2015

[5] Hulshoff Pol. L. S., de Zeeuw, W. J.; Velzeboer, C. T. M.; and Lettinga, G. Granulation in UASB-Reactor. Water Science and Technology, 15,291-304. 1983.

[6] Barbuśiński K., Innowacyjne technologie oczyszczania ścieków komunalnych - kierunki rozwoju, Napędy i Sterowanie 2016, p. 40-45.

[7] Draaijer, H., Maas, J. A., Schaapman J. E., Chan A., Performance of the 5 MLD UASB Reactor for Sewage Treatment at Kanpur, India. Water Science Technology, 123-133.1992.

[8] Jules B. Van Lier, Anand Vashi, Jeroen Van Der Lubbe, Barry Heffernan, Anaerobic Sewage Treatment using UASB Reactors, Engineering and Operational Aspects. Environmental Anaerobic Technology: pp. 59-89. 2010.

[9] Mahmoud, N., Zeeman, G. and van Lier J.B. Adapting UASB technology for sewage treatment in Palestine and Jordan. Wat. Sci. Technol. 57(3), 361-366. 2008.

[10] Barber, W. P., Stuckey, D. C., The use of anaerobic baffled reactor (ABR) for the wastewater treatment: A review. Water Research, v. 33, n. 7, p. 1559-1578 (1999). 
[11] Motteran F., Pereira E.L, Campos C.M., The behaviour of an anaerobic baffled reactor (ABR) as the first stage in the biological treatment of hog farming effluents; Brazilian Journal of Chemical Engineering. Sao Paulo 2013.

[12] Herum, B.A., Effects of Applied Vacuum on the Performance of the Anaerobic Sequencing Batch Reactor. Proceedings of the 48th Annual Industrial Waste Conference, Purdue University, West Lafayette, Indiana, May 1993.

[13] http://www.sswm.info/category/implementation-tools/wastewater-treatment/hardware/semi-centralisedwastewater-treatments-8 access 23.10.2017.

[14] Angenent L.T., and Sung S., (2001). Development of anaerobic migrating blanket reactor (AMBR), a novel anaerobic treatment system. 1739-1747 Department of Civil and Construction Engineering, Iowa State University, 2001.

[15] https://microbewiki.kenyon.edu/index.php/Methanogenic_Anaerobic_Digestion_of_Wastewater access_23.10.2017

[16] Pidaparti S.R., Anaerobic Sequencing Batch Reactor Treatment of Swine Wastes at $35^{\circ} \mathrm{C}$ and $25^{\circ} \mathrm{C}$. M Thesis, Iowa State University, Ames, Iowa 1992.

[17] Ndon, U.J., Anaerobic sequencing batch reactor treatment of low strength wastewater, Iowa State University, Iowa. 1995.

[18] Lew B., Tarre S., Beliavski M., Dosoretz C., Green M., Anaerobic Membrane Bioreactor (AnMBR) for Domestic Wastewater Treatment, Desalination, Vol. 243, No. 1-3, 2009, pp. 251-257.

[19] Baek S. H., Pagilla K. R., Kim H. J., Lab-Scale Study of an Anaerobic Membrane Bioreactor (AnMBR) for Dilute Municipal Wastewater Treatment, Biotechnology and Bioprocess Engineering, Vol. 15, No. 4, 2010, pp. 704-708.

[20] Anderson G.K., Kasapgil B., Ince O., Microbial Kinetics of a Membrane Anaerobic Reactor, Environmental Technology, Vol. 17, No. 5, 1996, p. 449.

[21] Chang S., Anaerobic Membrane Bioreactors (AnMBR) for Wastewater Treatment. Advances in Chemical Engineering and Science, 2014, 4, 56-61, School of Engineering, University of Guelph, Guelph, Canada 2014.

[22] http://www.ppeko.com.pl/produkty/oczyszczanie-beztlenowe/Reaktory\%20wiezowe.aspx access 23.10.2017.

[23] Medhat M.A. Saleh, Usama F. Mahmood,; UASB/EGSB APPLICATIONS FOR INDUSTRIAL WASTEWATER TREATMENT Seventh International Water Technology Conference Egypt 1-3 April 2003.

[24] Yoochatchaval W., Ohashi, A., Harada H., Yamaguchi T., Syutsubo K., Characteristics of Granular Sludge in an EGSB Reactor for Treating low Strength Wastewater. Int. J. Environ. Res., 2(4): 319-328, Niigata Japan 2008.

\section{Acknowledgments:}

The work was financed by Kielce University of Technology, part of the statutory work No. 05.0.10.00/2.01.01.01.0007 MNSP.IKTW.17.002

\section{Podziękowania:}

Praca była finansowana przez Politechnikę Świętokrzyska, w ramach pracy statutowej $n r$ : 05.0.10.00/2.01.01.01.0007 MNSP.IKTW.17.002 